\title{
Streptococcus porcorum sp. nov., isolated from domestic and wild pigs
}

\section{Correspondence \\ J. F. Fernández-Garayzábal garayzab@vet.ucm.es}

\author{
A. I. Vela, ${ }^{1,2}$ V. Sánchez, ${ }^{1}$ G. Mentaberre, ${ }^{3}$ S. Lavín, ${ }^{3}$ L. Domínguez ${ }^{1}$ \\ and J. F. Fernández-Garayzábal ${ }^{1,2}$
${ }^{1}$ Centro de Vigilancia Sanitaria Veterinaria (VISAVET), Universidad Complutense, 28040 Madrid, Spain
${ }^{2}$ Departamento de Sanidad Animal, Facultad de Veterinaria, Universidad Complutense, 28040 Madrid, Spain
${ }^{3}$ Departament Medicina i Cirurgia Animal, Facultat Veterinària, UAB, Bellaterra, 08193 Barcelona, Spain

The genus Streptococcus has undergone significant expansion due to improved phenotypic and molecular identification methods, and includes 65 recognized species at the time of writing (Euzéby, 1997; http://www.bacterio.cict.

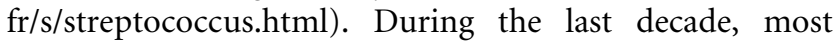
novel streptococcal species have been isolated from animal sources (Collins et al., 2001, 2002; Lawson et al., 2005a, b; Takada \& Hirasawa, 2007; Vela et al., 2009). Animal streptococci have been isolated from a wide range of environments (Kilian, 1998) and some of them have been associated with a variety of diseases such as endometritis, respiratory infections, endocarditis, meningitis, arthritis and mastitis (Chanter, 1997; Köhler, 2007). During routine microbiological diagnosis from clinical specimens

The GenBank/EMBL/DDBJ accession numbers for the 16S rRNA, rpo $B$ and sod $A$ gene sequences of strain $682-03^{\top}$ are FN643224, FN814308 and FN814309, respectively; those for the 16S rRNA gene sequences of strains 1606/02, 1792/03, 1561-2D2/04, 1561-9D2/ 04, 183/08 and 229/08 are AJ871184 and FN908165-FN908169, respectively.

A supplementary figure and table are available with the online version of this paper. submitted to the Animal Health Surveillance Centre (VISAVET) of the Universidad Complutense (Madrid, Spain), we have characterized seven Streptococcus-like organisms using phenotypic and molecular-genetics methods. The unidentified Gram-stain-positive, coccoid organisms were recovered from pigs (strains $682-03^{\mathrm{T}}, 1606-02$ and 1792-03) and wild boar (183-08 and 229-08) in Spain and pigs in Chile (1561-2D2-04 and 1561-9D2-04) (strain designations formed from strain number-year of isolation). The strains were isolated from pleura (1606-02) and lungs (1792-03, 1561-2D2-04 and 1561-9D2-04) of four pigs with lesions of pneumonia, a joint of a pig with arthritis $\left(682-03^{\mathrm{T}}\right)$ and tonsils from two apparently healthy wild boars (183-08 and 229-08). Strains were isolated on Columbia blood agar plates (bioMérieux) incubated for $24 \mathrm{~h}$ at $37^{\circ} \mathrm{C}$ under both aerobic and anaerobic [with 4$10 \% \mathrm{CO}_{2}$ using the GasPak Plus system (BBL)] conditions. On the basis of the phenotypic and phylogenetic results, a novel species of the genus Streptococcus is proposed to accommodate the strains.

In order to determine the phylogenetic relations of the isolates, almost the entire 16S rRNA gene of each isolate 
was sequenced and subjected to comparative analysis as described previously (Vela et al., 2002). Sequences of a large continuous fragment (approx. 1390 bases) of the 16S rRNA genes of two isolates $\left(1606-02\right.$ and $682-03^{\mathrm{T}}$ ) and $1000 \mathrm{nt}$ from isolates 1792-03, 1561-2D2-04, 1561-9D2-04, 183-08 and 229-08 were obtained by bidirectional sequencing using universal primers pA (5'-AGAGTTTGATCCTGGCTCAG; positions 8-27, Escherichia coli numbering) and $\mathrm{pH}^{\star}$ (5'-AAGGAGGTGATCCAGCCGCA; 15411522). Comparative sequence analysis revealed 99.3$100 \%$ sequence similarity between the strains, thereby demonstrating their high genetic relatedness. Sequence searches of GenBank using the program FASTA (Pearson, 1994) revealed that the unknown cocci exhibited the highest 16S rRNA gene sequence similarity with Streptococcus suis ATCC $43765^{\mathrm{T}}$ (97.5\%). The next most closely related type strains were Streptococcus gordonii ATCC $10558^{\mathrm{T}}$ (97.2 \% similarity), S. urinalis $2285-97^{\mathrm{T}}$ (97.2\%), S. lutetiensis NEM $782^{\mathrm{T}}(97.2 \%)$, S. infantarius HDP $90056^{\mathrm{T}}$ $(97.1 \%)$, S. equinus CCUG $27302^{\mathrm{T}}$ and S. alactolyticus ATCC $43077^{\mathrm{T}}(97.1 \%)$. These sequences and those of other representative species within the genus Streptococcus were retrieved from GenBank and aligned with the newly determined sequences using the program SEQtools (Rasmussen, 2002). Phylogenetic trees were reconstructed according to three different methods, the neighbourjoining algorithm (Saitou \& Nei, 1987), performed with the programs SEQtools and TreeView (Page, 1996; Rasmussen, 2002), maximum-likelihood analysis using the PHYML software (Guindon \& Gascuel, 2003) and the maximum-parsimony method carried out using the software package MEGA version 3.1 (Kumar et al., 2004). Genetic distances for the neighbour-joining and maximum-likelihood algorithms were calculated by Kimura's two-parameter model (Kimura, 1980) and close-neighbour-interchange ( search level $=2$, random additions $=100$ ) was applied in maximum-parsimony analysis. The stability of the groupings was estimated by bootstrap analysis (1000 replications). Phylogenetic trees obtained by using the neighbour-joining method (Fig. 1) and the other two methods (not shown) revealed a clear affiliation of the unknown cocci (exemplified by strain $682-03^{\mathrm{T}}$ ) to the genus Streptococcus. It is evident from Fig. 1 that strain $682-03^{\mathrm{T}}$ displays a phylogenetic affinity with a subcluster of species consisting of S. suis, Streptococcus porci and Streptococcus plurextorum; however, the branching of the strain at the base of this subcluster was not supported by bootstrap analysis of the neighbour-joining tree $(<50 \%$ support) or the other treeing methods (not shown).

Sequence analysis of the sod $A$ and $r p o B$ genes has been shown to be a useful tool for differentiating streptococci on phylogenetic grounds (Poyart et al., 1998, 2002; Drancourt et al., 2004). Partial sequences of $r p o B$ (701 bp) and sodA (356 bp) were amplified and sequenced as described previously (Glazunova et al., 2006). Evolutionary distances were calculated using Kimura's two-parameter model (Kimura, 1980) and trees were reconstructed using the

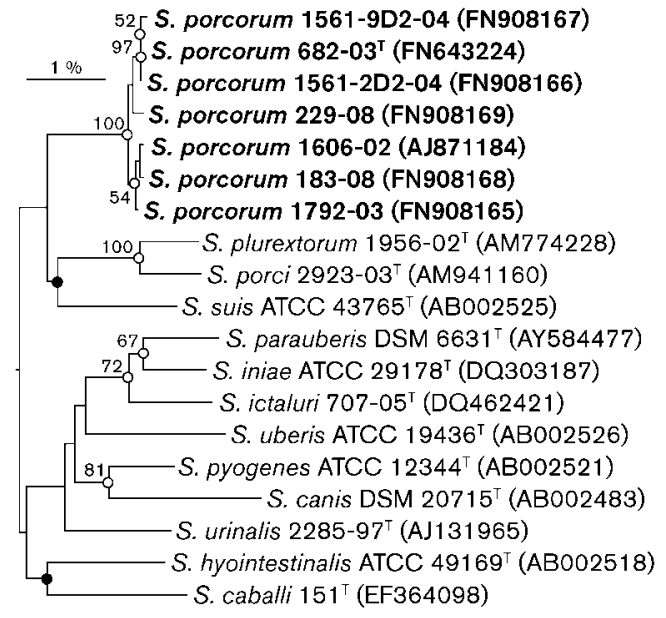

Fig. 1. Phylogenetic tree inferred from 16S rRNA gene sequence comparisons using the neighbour-joining method, showing the relationships of the novel strains (Streptococcus porcorum sp. nov.) and their closest phylogenetic neighbours. Enterococcus faecalis ATCC $19433^{\top}$ (not shown) was used as an outgroup to generate the full version of the phylogenetic tree, which included all currently recognized Streptococcus species. Bootstrap values (expressed as percentages of 1000 replications) higher than $50 \%$ are given at branching points. Open circles indicate that the corresponding nodes (groupings) were also obtained in maximumlikelihood and maximum-parsimony trees; filled circles indicate that the corresponding nodes (groupings) were also obtained in maximum-parsimony trees. Bar, $1 \%$ sequence divergence.

neighbour-joining method (Saitou \& Nei, 1987). Bootstrap values (1000 replicates) were also calculated. The seven isolates showed high sequence similarity in the two gene sequences: $97.5-99.7 \%$ for $r p o B$ and $97.7-99.8 \%$ for $\operatorname{sod} A$. Strain $682-03^{\mathrm{T}}$ formed a branch separate from other Streptococcus species in phylogenetic trees inferred from $r p o B$ and sodA gene sequence comparisons (Supplementary Fig. S1, available in IJSEM Online); the highest sequence similarity based on the $r p o B$ gene was between strain 682$03^{\mathrm{T}}$ and Streptococcus canis CIP $103223^{\mathrm{T}}(88.5 \%)$, while the highest sequence similarity based on the sodA gene was to S. suis CIP $103217^{\mathrm{T}}(81.4 \%)$. Glazunova et al. (2009) evaluated the discriminatory power of the $r p o B$ and $\operatorname{sod} A$ genes for the identification of strains of 58 species of Streptococcus with validly published names and found that the similarity between pairs of species was in most cases between 80 and $90 \%$ for the $r p o B$ gene and $70-80 \%$ for the sodA gene (Glazunova et al., 2009). These similarities are similar to those obtained between strain $682-03^{\mathrm{T}}$ and streptococcal species that were phylogenetically closely related on the basis of the $16 \mathrm{~S}$ rRNA gene. Strain $682-03^{\mathrm{T}}$ exhibited a mean $r p o B$ gene sequence similarity of $84.8 \%$, ranging from $86.2 \%$ (S. alactolyticus) to $83.4 \%$ ( $S$. gordonii). The mean sequence similarity for the sodA gene was $73.1 \%$, ranging from $81.4 \%$ (S. suis) to $66.7 \%$ ( $S$. lutetiensis). Thus, minimum interspecies divergence values 
of 13.8 and $18.6 \%$ for the $r p o B$ and sodA genes, respectively, between strain $682-03^{\mathrm{T}}$ and it closest relatives based on 16S rRNA gene sequence phylogeny support separate species status for the unidentified catalasenegative cocci from domestic and wild pigs.

DNA-DNA hybridization experiments were carried out between strain $682-03^{\mathrm{T}}$ and its nearest phylogenetic neighbour, S. suis NCTC $10234^{\mathrm{T}}$, and between strain 682$03^{\mathrm{T}}$ and strains $229-08$ and 1792-03. Genomic DNA was isolated using a French pressure cell (Thermo Spectronic) and purified by chromatography on hydroxyapatite as described by Cashion et al. (1977). DNA-DNA hybridization was carried out in $2 \times \mathrm{SSC}$ at $68{ }^{\circ} \mathrm{C}$ by the Identification Service of the DSMZ (Braunschweig, Germany) using the method described by De Ley et al. (1970) under consideration of the modifications described by Huß et al. (1983) with a model Cary 100 Bio UV/Vis spectrophotometer equipped with a Peltier-thermostatted $6 \times 6$ multicell changer and a temperature controller with in situ temperature probe (Varian). The DNA-DNA hybridization study between the three new isolates showed 80 92.4\% DNA relatedness between them, demonstrating that they are members of the same species (Wayne et al., 1987). The DNA-DNA reassociation between strain $682-03^{\mathrm{T}}$ and S. suis NCTC $10234^{\mathrm{T}}$ was $8-18 \%$, clearly confirming that the new isolates constitute a separate species (Wayne et al., 1987).

The $\mathrm{G}+\mathrm{C}$ content of the DNA of representative isolate $682-03^{\mathrm{T}}$ was determined at the DSMZ by using the HPLC method of Mesbah et al. (1989). The G+C content of strain $682-03^{\mathrm{T}}$ was $38.9 \mathrm{~mol} \%$.

The seven new isolates were Gram-stained and assessed for the presence of catalase. The haemolytic reaction was determined on Columbia agar containing $5 \%$ defibrinated sheep blood (bioMérieux) incubated aerobically at $37{ }^{\circ} \mathrm{C}$ for 24 and 48 h (Facklam \& Elliott, 1995). Determination of growth at $10,22,30,37$ and $42{ }^{\circ} \mathrm{C}$ and with $3,4.5$ and $6.5 \%$ added $\mathrm{NaCl}$ in brain heart infusion broth (Difco) at $\mathrm{pH} 7.5$ was performed as recommended by Facklam \& Elliott (1995). The Lancefield serological group reaction was determined with the commercial Slidex Strepto kit (bioMérieux) by using specific group A, B, C, D, F and G streptococcal latex agglutinating antisera. The isolates were characterized biochemically using the Rapid ID 32 Strep, API $50 \mathrm{CH}$ and API ZYM systems (bioMérieux) according to the manufacturer's instructions. Results from API $50 \mathrm{CH}$ strips using $\mathrm{CHB}$ suspension medium were followed for 7 days of incubation at $37^{\circ} \mathrm{C}$. The isolates exhibited almost identical biochemical characteristics, except for the acidification of raffinose (isolates 1561-2D2-04 and 1561-9D2-04 were negative) and inulin (isolates 183-08 and 229-08 were positive) and production of $\alpha$-galactosidase (isolates 160602 and 1561-9D2-04 were positive) and acetoin (isolates 229-08 and 1561-9D2-04 were positive). The phenotypic characteristics that differentiate the proposed species from closely related species are shown in Table 1 .
16S rRNA gene sequencing has revealed that the genus Streptococcus includes distinct 'species groups' that can be separated based on several microbiological tests (Whiley \& Hardie, 2009). Characteristics that differentiate the proposed novel species from these streptococcal 'species groups' are indicated in Supplementary Table S1. The new isolates could also be distinguished from other Streptococcus species isolated from pigs by several phenotypic characteristics such as the haemolytic reaction in blood agar and identification of Lancefield group antigens,

Table 1. Characteristics useful in differentiating Streptococcus porcorum sp. nov. from other streptococci that are phylogenetically closely related based on 16S rRNA gene tree topology using the neighbour-joining method

Strains: 1, S. porcorum $682-03^{\mathrm{T}} ; 2$, S. porci $2923-02^{\mathrm{T}} ; 3$, S. plurextorum $1956-02^{\mathrm{T}} ; 4$, S. suis CCUG $7984^{\mathrm{T}} ; 5$, S. pyogenes CCUG $4207^{\mathrm{T}}$ (included as a representative of the type species of the genus). + , Positive reaction; -, negative reaction. NG, non-groupable. Lancefield serological group reaction was determined using group A-, B-, C-, D-, F- and G-specific streptococcal latex agglutinating antisera (bioMérieux). Phenotypic data were obtained in this study.

\begin{tabular}{|c|c|c|c|c|c|}
\hline Characteristic & 1 & 2 & 3 & 4 & 5 \\
\hline Lancefield antigen & NG & B & $\mathrm{B}$ & $\mathrm{D}$ & A \\
\hline Hydrolysis of arginine & - & - & - & + & + \\
\hline \multicolumn{6}{|l|}{ Production of: } \\
\hline$\beta$-Glucosidase & + & + & - & + & - \\
\hline$\beta$-Glucuronidase & - & - & + & + & - \\
\hline$\alpha$-Galactosidase & - & + & + & + & - \\
\hline Glycyl-tryptophan arylamidase & - & + & + & + & - \\
\hline Esterase $(\mathrm{C} 4)$ & - & - & - & + & + \\
\hline Esterase lipase (C8) & - & - & - & + & - \\
\hline Alkaline phosphatase & - & - & - & - & + \\
\hline Acid phosphatase & + & - & + & - & + \\
\hline$\beta$-Galactosidase & - & + & + & + & - \\
\hline$\alpha$-Glucosidase & - & + & - & + & + \\
\hline $\begin{array}{l}\text { Naphthol-AS-BI- } \\
\text { phosphohydrolase }\end{array}$ & - & - & - & - & + \\
\hline$N$-Acetyl- $\beta$-glucosaminidase & - & - & - & + & - \\
\hline Pyroglutamic acid arylamidase & - & - & - & + & + \\
\hline Valine arylamidase & - & - & - & - & + \\
\hline Cystine arylamidase & - & - & - & - & + \\
\hline \multicolumn{6}{|l|}{ Production of acid from: } \\
\hline Pullulan & - & + & - & + & + \\
\hline Raffinose & + & + & + & + & - \\
\hline Melibiose & - & + & - & - & - \\
\hline Methyl $\beta$-D-glucopyranoside & + & - & - & + & + \\
\hline L-Arabinose & - & + & - & - & - \\
\hline D-Xylose & - & + & - & - & - \\
\hline Amygdalin & + & - & - & - & + \\
\hline Cellobiose & + & + & - & + & + \\
\hline Inulin & - & - & - & + & - \\
\hline Starch & - & + & - & + & + \\
\hline Glycogen & - & + & - & + & + \\
\hline Gentiobiose & + & - & - & - & - \\
\hline
\end{tabular}


tests that are very useful for differentiating streptococci in clinical laboratories. Thus, Streptococcus porcinus and Streptococcus dysgalactiae subsp. equisimilis are $\beta$-haemolytic and react with different Lancefield group antisera (Facklam, 2002) and Streptococcus orisuis, Streptococcus ferus and Streptococcus dentapri are non-haemolytic (Baele et al., 2003; Takada \& Hirasawa, 2007; Takada et al., 2010). Streptococcus thoraltensis, Streptococcus hyovaginalis and Streptococcus hyointestinalis are also $\alpha$-haemolytic and do not react with Lancefield group A, B, C, D, F or G streptococcal antisera. However, these species are acetoin(Voges-Proskauer test) and alkaline phosphatase-positive (Devriese et al., 1988, 1997), while the proposed novel species is negative for both tests.

Based on the data presented, we consider the new isolates to represent a novel Streptococcus species, for which the name Streptococcus porcorum sp. nov. is proposed. Isolates were recovered from different animals in different years and different geographical regions of two countries. Therefore, it is very unlikely that the isolates could have any epidemiological clonality. Given that two of the isolates were obtained from apparently healthy animals and only two isolates from clinical samples were isolated in pure culture from the lungs of two pigs with pneumonia, it is not possible to reach conclusions about any pathogenic role of this Streptococcus species towards domestic or wild animals.

\section{Description of Streptococcus porcorum sp. nov.}

Streptococcus porcorum (por.co'rum. L. n. porcus $-i$ a hog, pig; L. gen. pl. n. porcorum of/from pigs).

Cells are Gram-stain-positive, non-spore-forming cocci, $0.5-1 \mu \mathrm{m}$ in diameter, occurring in pairs or in chains, commonly over 15 cells long. Colonies on blood agar are small, circular and non-pigmented, $0.75-1.0 \mathrm{~mm}$ in diameter and $\alpha$-haemolytic at $37^{\circ} \mathrm{C}$. Cells are facultatively anaerobic, catalase-negative and non-motile. No Lancefield carbohydrate antigens (Slidex Strepto kit; bioMérieux) are detected. Cells are able to grow at 10, 22, 30, 37 and $42{ }^{\circ} \mathrm{C}$ but do not grow in the presence of 3, 4.5 or $6.5 \% \mathrm{NaCl}$. With the API $50 \mathrm{CH}$ and Rapid ID32 Strep kits, acid is produced from lactose, D-glucose, D-fructose, trehalose, maltose, methyl $\beta$-D-glucopyranoside, D-galactose, D-mannose, $\mathrm{N}$-acetylglucosamine, arbutin, amygdalin, aesculin, salicin, cellobiose, gentiobiose and sucrose but not from melibiose, L- or D-arabinose, D-xylose, starch, glycerol, erythritol, D-ribose, L-xylose, D-adonitol, L- or D-arabitol, glycogen, D-mannitol, inositol, dulcitol, melezitose, Lrhamnose, methyl $\alpha$-D-mannopyranoside, pullulan, methyl $\alpha$-D-glucopyranoside, L-sorbose, turanose, methyl $\beta$-D-xylopyranoside, D-lyxose, xylitol, D- or L-fucose, Dsorbitol, 2-ketogluconate, 5-ketogluconate, cyclodextrin or tagatose. Most strains produce acid from raffinose (Rapid ID32 Strep; type strain positive) but not from inulin (API $50 \mathrm{CH}$; type strain negative). Leucine arylamidase, acid phosphatase (API ZYM), $\beta$-glucosidase and alanine-phenylalanine-proline arylamidase (Rapid ID32 Strep) are detected. No activity is detected for $\mathrm{N}$-acetyl$\beta$-glucosaminidase, naphthol-AS-BI-phosphohydrolase, $\alpha$-mannosidase, $\alpha$-fucosidase, esterase (C4), esterase lipase (C8), lipase (C14), valine arylamidase, $\beta$-galactosidase, $\alpha$-glucosidase, cystine arylamidase, trypsin, $\alpha$-chymotrypsin (API ZYM), alkaline phosphatase, $\beta$-glucuronidase (API ZYM and Rapid ID32 Strep), glycyl-tryptophan arylamidase, $\beta$-mannosidase or pyroglutamic acid arylamidase (Rapid ID32 Strep). Arginine, hippurate and urea are not hydrolysed (Rapid ID32 Strep). Most strains do not produce $\alpha$-galactosidase or acetoin (Rapid ID32 Strep; type strain negative for both tests).

The type strain, $682-03^{\mathrm{T}}\left(=\right.$ CECT $7593^{\mathrm{T}}=$ CCUG $\left.58479^{\mathrm{T}}\right)$, was isolated from a joint of a pig with arthritis. Full range of habitats is not known. The DNA G $+\mathrm{C}$ content of the type strain is $38.9 \mathrm{~mol} \%$.

\section{Acknowledgements}

This work was funded by the Spanish Ministry of Education and Science (MEC) (projects FAU 2006-00011-CO2-02 and AGL2009-14303-C0201). The authors thank Professor J. P. Euzéby, Ecole Nationale Vétérinaire, Toulouse, for advice on the Latin species name, A. Casamayor for technical assistance and Juncal Fernández-Garayzábal for her assistance with the English reviewing of the manuscript.

\section{References}

Baele, M., Devriese, L. A., Vancanneyt, M., Vaneechoutte, M., Snauwaert, C., Swings, J. \& Haesebrouck, F. (2003). Emended description of Streptococcus ferus isolated from pigs and rats. Int J Syst Evol Microbiol 53, 143-146.

Cashion, P., Holder-Franklin, M. A., McCully, J. \& Franklin, M. (1977). A rapid method for the base ratio determination of bacterial DNA. Anal Biochem 81, 461-466.

Chanter, N. (1997). Streptococci and enterococci as animal pathogens. Soc Appl Bacteriol Symp Ser 26 (Suppl.), 100S-109S.

Collins, M. D., Hutson, R. A., Hoyles, L., Falsen, E., Nikolaitchouk, N. \& Foster, G. (2001). Streptococcus ovis sp. nov., isolated from sheep. Int J Syst Evol Microbiol 51, 1147-1150.

Collins, M. D., Hutson, R. A., Falsen, E., Inganäs, E. \& Bisgaard, M. (2002). Streptococcus gallinaceus sp. nov., from chickens. Int J Syst Evol Microbiol 52, 1161-1164.

De Ley, J., Cattoir, H. \& Reynaerts, A. (1970). The quantitative measurement of DNA hybridization from renaturation rates. Eur $J$ Biochem 12, 133-142.

Devriese, L. A., Kilpper-Bälz, R. \& Schleifer, K. H. (1988). Streptococcus hyointestinalis sp. nov. from the gut of swine. Int $J$ Syst Bacteriol 38, 440-441.

Devriese, L. A., Pot, B., Vandamme, P., Kersters, K., Collins, M. D., Alvarez, N., Haesebrouck, F. \& Hommez, J. (1997). Streptococcus hyovaginalis sp. nov. and Streptococcus thoraltensis sp. nov., from the genital tract of sows. Int J Syst Bacteriol 47, 1073-1077.

Drancourt, M., Roux, V., Fournier, P. E. \& Raoult, D. (2004). rpoB gene sequence-based identification of aerobic Gram-positive cocci of the genera Streptococcus, Enterococcus, Gemella, Abiotrophia, and Granulicatella. J Clin Microbiol 42, 497-504. 
Euzéby, J. P. (1997). List of bacterial names with standing in nomenclature: a folder available on the Internet. Int J Syst Bacteriol 47, 590-592.

Facklam, R. (2002). What happened to the streptococci: overview of taxonomic and nomenclature changes. Clin Microbiol Rev 15, 613630.

Facklam, R. R. \& Elliott, J. A. (1995). Identification, classification, and clinical relevance of catalase-negative, gram-positive cocci, excluding the streptococci and enterococci. Clin Microbiol Rev 8, 479-495.

Glazunova, O. O., Raoult, D. \& Roux, V. (2006). Streptococcus massiliensis sp. nov., isolated from a patient blood culture. Int J Syst Evol Microbiol 56, 1127-1131.

Glazunova, O. O., Raoult, D. \& Roux, V. (2009). Partial sequence comparison of the $r p o B$, sodA, groEL and $g y r B$ genes within the genus Streptococcus. Int J Syst Evol Microbiol 59, 2317-2322.

Guindon, S. \& Gascuel, O. (2003). A simple, fast, and accurate algorithm to estimate large phylogenies by maximum likelihood. Syst Biol 52, 696-704.

Huß, V. A. R., Festl, H. \& Schleifer, K. H. (1983). Studies on the spectrophotometric determination of DNA hybridization from renaturation rates. Syst Appl Microbiol 4, 184-192.

Kilian, M. (1998). Streptococcus and Lactococcus. In Topley \& Wilson's Microbiology and Microbial Infections, vol. 2, pp. 633-667. Edited by A. Balows \& B. I. Duerden. London: Arnold.

Kimura, M. (1980). A simple method for estimating evolutionary rates of base substitutions through comparative studies of nucleotide sequences. J Mol Evol 16, 111-120.

Köhler, W. (2007). The present state of species within the genera Streptococcus and Enterococcus. Int J Med Microbiol 297, 133-150.

Kumar, S., Tamura, K. \& Nei, M. (2004). MEGA3: integrated software for molecular evolutionary genetics analysis and sequence alignment. Brief Bioinform 5, 150-163.

Lawson, P. A., Foster, G., Falsen, E. \& Collins, M. D. (2005a). Streptococcus marimammalium sp. nov., isolated from seals. Int J Syst Evol Microbiol 55, 271-274.

Lawson, P. A., Foster, G. A., Falsen, E., Markopoulos, S. J. \& Collins, M. D. (2005b). Streptococcus castoreus sp. nov., isolated from a beaver (Castor fiber). Int J Syst Evol Microbiol 55, 843-846.

Mesbah, M., Premachandran, U. \& Whitman, W. B. (1989). Precise measurement of the $\mathrm{G}+\mathrm{C}$ content of deoxyribonucleic acid by highperformance liquid chromatography. Int J Syst Bacteriol 39, 159167.
Page, R. D. M. (1996). TreeView: an application to display phylogenetic trees on personal computers. Comput Appl Biosci 12, 357-358.

Pearson, W. R. (1994). Using the FASTA program to search protein and DNA sequence databases. Methods Mol Biol 24, 307-331.

Poyart, C., Quesne, G., Coulon, S., Berche, P. \& Trieu-Cuot, P. (1998). Identification of streptococci to species level by sequencing the gene encoding the manganese-dependent superoxide dismutase. J Clin Microbiol 36, 41-47.

Poyart, C., Quesne, G. \& Trieu-Cuot, P. (2002). Taxonomic dissection of the Streptococcus bovis group by analysis of manganese-dependent superoxide dismutase gene ( $\operatorname{sod} A$ ) sequences: reclassification of 'Streptococcus infantarius subsp. coli' as Streptococcus lutetiensis sp. nov. and of Streptococcus bovis biotype 11.2 as Streptococcus pasteurianus sp. nov. Int J Syst Evol Microbiol 52, 1247-1255.

Rasmussen, S. W. (2002). SEQtools, a program suite for sequence analysis. http://www.seqtools.dk

Saitou, N. \& Nei, M. (1987). The neighbor-joining method: a new method for reconstructing phylogenetic trees. Mol Biol Evol 4, 406425.

Takada, K. \& Hirasawa, M. (2007). Streptococcus orisuis sp. nov., isolated from the pig oral cavity. Int J Syst Evol Microbiol 57, 12721275.

Takada, K., Hayashi, K., Sato, Y. \& Hirasawa, M. (2010). Streptococcus dentapri sp. nov., isolated from the wild boar oral cavity. Int J Syst Evol Microbiol 60, 820-823.

Vela, A. I., Fernández, E., Lawson, P. A., Latre, M. V., Falsen, E., Dominguez, L., Collins, M. D. \& Fernández-Garayzábal, J. F. (2002). Streptococcus entericus sp. nov., isolated from cattle intestine. Int J Syst Evol Microbiol 52, 665-669.

Vela, A. I., Casamayor, A., Sánchez Del Rey, V., Domínguez, L. \& Fernández-Garayzábal, J. F. (2009). Streptococcus plurextorum sp. nov., isolated from pigs. Int J Syst Evol Microbiol 59, 504-508.

Wayne, L. G., Brenner, D. J., Colwell, R. R., Grimont, P. A. D., Kandler, O., Krichevsky, M. I., Moore, L. H., Moore, W. E. C., Murray, R. G. E. \& other authors (1987). International Committee on Systematic Bacteriology. Report of the ad hoc committee on reconciliation of approaches to bacterial systematics. Int J Syst Bacteriol 37, 463-464.

Whiley, R. A. \& Hardie, J. M. (2009). Genus I. Streptococcus Rosenbach $1884,22^{\mathrm{AL}}$. In Bergey's Manual of Systematic Bacteriology, 2nd edn, vol. 3, pp. 655-711. Edited by P. De Vos, G. M. Garrity, D. Jones, N. R. Krieg, W. Ludwig, F. A. Rainey, K. H. Schleifer \& W. B. Whitman. New York: Springer. 